\title{
Psykiske og hormonelle reaksjoner i svangerskapet relatert til funn av utviklingsavvik hos fosteret
}

\author{
Anne Kaasen og Guttorm Haugen \\ Seksjon for fostermedisin og ultralyd, Kvinneklinikken, Rikshospitalet, Oslo Universitetssykehus, \\ og Universitetet i Oslo \\ Korrespondanse: Anne Kaasen, Seksjon for fostermedisin og ultralyd, Kvinneklinikken, Rikshospitalet, Oslo Universitetssykehus, 0027 Oslo \\ Telefon: +4790746802 E-post: a.kaasen@online.no
}

\begin{abstract}
SAMMENDRAG
Funn av avvik på fosteret medfører betydelig psykisk stress hos den gravide og hennes partner. Kunnskap om forholdet mellom psykologiske og fysiologiske reaksjoner på stress er relativt bra belyst hos kvinner som ikke er gravide. Dette kan ikke uten videre overføres til gravide fordi svangerskapet i seg selv medfører store endringer i hormonbalansen. Vi undersøker relasjonen mellom psykisk stress og hormonell stressrespons hos gravide hvor det påvises fosteravvik ved hjelp av ultralyd.
\end{abstract}

\section{Kaasen A, Haugen G. Psychological and hormonal reactions in pregnancy related to developmental abnormalities in the offspring. Nor J Epidemiol 2009; 19 (1): 69-72.}

\section{ENGLISH SUMMARY}

Detection of a fetal anomaly leads to considerable psychological distress for the pregnant woman and her partner. The relation between psychological and endocrine reactions to stress is relatively well understood in non-pregnant women. This knowledge is not necessarily transferable to the situation during pregnancy because pregnancy itself causes alterations in the maternal hormone balance. We are studying the relation between psychological and endocrine stress responses in pregnancies following the detection of fetal anomalies by ultrasonography.

\section{INTRODUKSJON}

Tilbudet om rutineultralyd benyttes av mellom 96 og $97 \%$ av de gravide i Norge (tall fra Medisinsk fødselsregister (MFR), Folkehelseinstituttet, 1999-2006). Forekomsten av medfødte misdannelser totalt registrert $\mathrm{i}$ MFR har ligget nokså stabilt rundt 3\%. Det er grunn til å anta at det foreligger en viss grad av underrapportering (1). De siste decennier har oppdagelse av medfødte strukturelle avvik ved ultralydundersøkelse økt betydelig (2). I svangerskapet er det generelt lite kunnskap om psykologiske reaksjoner, spesielt i forbindelse med avdekking av fosteravvik ved hjelp av ultralyd. Vi ønsker å undersøke hvor mye stress foreldrene opplever etter oppdagelse av fosteravvik, i den resterende delen av svangerskapet og i tiden etter fødsel, og å relatere dette til hormonelle stressresponser.

\section{PSYKISKE REAKSJONER}

Alvorlig depresjon og psykotiske tilstander relatert til svangerskap og fødsel forekommer først og fremst i tiden etter fødselen (3). Nyere forskning med bruk av psykometriske tester har imidlertid ikke vist øket forekomst av lettere depresjoner i barseltiden sammenlignet med selve svangerskapet eller med andre tidspunkt $i$ en kvinnes liv (4). Dette understøttes i et norsk doktorgradsarbeid (5) hvor det ikke ble funnet forøket forekomst av depresjoner de første 8 måneder etter svangerskapet sammenlignet med siste del av svangerskapet (6). Skari et al. (7) viser i sin studie at fødsel ikke utløser varige psykiske plager hos foreldre. Derimot er negative livshendelser, dårlig forhold til partner og tidligere depressive problemer risikofaktorer for depresjon (8).

I motsetning til forskning omkring barseltiden foreligger det lite forskning om depresjon, angst og psykiske stressreaksjoner i selve svangerskapet. I en longitudinell studie fra England fant de en høyere forekomst av depresjon i svangerskapsuke 32 sammenlignet med uke 18 (9). Eberhard-Gran et al. (6) fant tilsvarende i en studie fra Norge. Begge studiene benyttet "Edinburgh Postnatal Depression Scale" (EPDS). Evans et al. (9) har påvist endring av angstnivå gjennom svangerskapet. Det er stilt spørsmål ved om angst i svangerskapet er en egen tilstand som reflekterer "angst for fødsel", "redsel for å bære et barn med handikap" og "bekymring for ens fremtoning" (10).

Prenatal diagnostikk med ultralydundersøkelser, fostervannsprøver og andre invasive undersøkelser er blitt en del av den moderne svangerskapsovervåkingen. Det er utført flere studier om psykisk helse relatert til selve ultralydundersøkelsen (11). Det er blant annet spekulert på om redusert angst etter undersøkel- 
sen avspeiler økt angst forut for undersøkelsen mer enn en reell reduksjon etter undersøkelsen (12), med andre ord at undersøkelsen ikke medfører redusert angst.

Påvisning av avvik ved fosteret representerer en psykisk påkjenning hos den gravide og hennes partner. Sklansky et al. (13) har evaluert hvilke psykiske innvirkninger føtal ekkokardiografi hadde på gravide. De fant økt angst ved funn av avvik og redusert angst der hvor det var normale funn. Etter fødselen fant man at kvinner med prenatalt diagnostisert hjertefeil hos barnet følte mindre ansvar for avviket. De hadde for øvrig forbedret forholdet til barnefar etter oppdagelsen av avviket prenatalt.

Leithner et al. (14) har også vist at et betydelig antall kvinner som gjennomgår prenatal diagnostikk som avdekker avvik, opplever psykisk stress. Kvinnene viste ekstrem høy skår på "general mood scale" og "anxiety scale" (målt med Mood Scales og State Trait Anxiety Inventory) sammenlignet med normalbefolkningen. Etter 6 måneder sank disse verdiene betydelig. Noen av de samme forfatterne har sett på erfaring av intervensjon med psykologisk hjelp etter prenatal diagnose. Studien konkluderer med at et slikt tilbud er viktig for disse kvinnene, spesielt til dem som har hatt en lignende opplevelse tidligere (15). Hos friske kvinner med pågående ukompliserte graviditeter som tidligere har vært gravide med et sykt barn fant for øvrig Brisch et al. (16) et høyere stressnivå sammenlignet med en kontrollgruppe.

Det er antatt at den veiledningen den gravide og hennes partner får $\mathrm{i}$ forbindelse med prenatal diagnostikk og påvisning av avvik ved fosteret er av betydning for den psykiske belastningen gjennom svangerskapet. Langer og Ringler (17) fant at nytten av veiledning var knyttet til akseptering av misdannelsen, både som en akseptering av et svangerskap med et foster med avvik, en akseptering av selve misdannelsen, og følelse av autonomi. I følge Kemp et al. (18) vil veiledning av kirurg angående prenatalt påviste avvik redusere nivået av foreldres angst. Dette sammenfaller med studiene til Aite et al. som i tre ulike artikler (19-21) har belyst betydningen av multidisiplinær og gjentatt veiledning for angstreduksjon hos mor etter prenatal oppdagelse av avvik som kan behandles kirurgisk. De viste for øvig at økt stress hos mor gjorde henne mindre mottagelig for viktige sider av veiledningen.

Betydningen av prenatal versus postnatal diagnose av medfødte misdannelser for den psykiske belastningen er omdiskutert. Sandelowski og Jones (22) trekker i sin artikkel frem at flere par syntes det var godt å vite diagnosen på forhånd. De følte imidlertid et psykisk vakuum ved å måtte avvente tilstanden til barnet. Hunfeld et al. (23) viste imidlertid at prenatal kjennskap til avvik medfører økt byrde og sorg i det første året etter fødselen i forhold til ikke å vite om avviket før etter fødselen. Dette er samsvarende med en større norsk studie (24) som viste høyere psykisk stressnivå etter prenatal versus postnatal diagnose av medfødte mis- dannelser, dog med mindre og ikke signifikant forskjell 6 mnd etter fødselen. Hunfeld et al. (23) viste for øvirg at prenatal veiledning med klar og konsistent informasjon om avviket og prognosen kan redusere unødvendig stress og usikkerhet. I tråd med dette er det påstått at ultralydundersøkelser har en "psykologisk kostnad" som kan reduseres med kunnskap om den subjektive opplevelsen til foreldre hvor fosteret har avvik når undersøkerne har øvelse i håndtering av slike foreldre (25). Strauss (26) har imidlertid hevdet at prenatal diagnose og veiledning i svangerskapet er hinsides enkle svar og påpeker at prenatal diagnostikk reiser etiske, familiemessige, politiske og rettslige spørsmål som har stor innvirkning på livene til barn født med spesielle helsebehov. Skari et al. (24) viste i sin analyse av stressreaksjoner etter fødsel av et barn med medfødte misdannelser at reaksjonen var mest uttalt hos foreldre som fikk prenatal diagnose i svangerskapsuke 25 til 30 sammenlignet med tiden før eller etter. Årsaken til dette kan være pasientseleksjon. Pasienter med tidlig diagnose og med sterk stressreaksjon kan ha valgt svangerskapsavbrudd. Forskjellene kan også være påvirket av mulige generelle forandringer av psykisk stressnivå gjennom svangerskapet. Det er bare utført noen få studier over mulige endringer av psykisk stressmønster gjennom svangerskapet $(6,9,10)$.

\section{HORMONELLE REAKSJONER}

Kortisol målt i spytt er fritt (ikke bundet til bæreproteiner) og reflekterer derfor hypothalamus-hypofysebinyre- (HPA-) aksen bedre enn serum kortisol (27). En studie har sett på stressreaksjon (målt ved psykometriske tester og konsentrasjon av kortisol i spytt) før og etter 3D-visning av fosteret rundt uke $30 \mathrm{i}$ svangerskapet hos kvinner med normale svangerskap. Stressnivå og konsentrasjonen av kortisol sank signifikant etter ultralydundersøkelsen (28). Uavhengig av ultralydundersøkelser har Obel et al. (29) undersøkt sammenhengen mellom stress og konsentrasjonen av kortisol i spytt ved ca. 14 og 30 ukers svangerskap. Sent $i$ svangerskapet steg konsentrasjonen av kortisol i spyttprøve tatt om kvelden ved stress, mens morgenverdien holdt seg uforandret. Tidlig i svangerskapet var det ingen forskjell på kortisolverdiene ved stress. Studien konkluderer med at reaksjonen på stress endrer seg gjennom svangerskapet. Kammerer et al. (30) fant imidlertid mot slutten av svangerskapet hos ikkedeprimerte gravide manglende kortisolrespons til en akutt stressor, mulig fordi HPA-aksen er påvirket av høye nivåer av "corticoreleasing hormone" (CRH) fra placenta. I samme studie ble det funnet at ratio av fritt kortisol og bundet kortisol er høyere i slutten enn i begynnelsen av svangerskapet.

Epidemiologiske studier peker i retning av at lav fødselsvekt er assosiert med en økt risiko for kardiovaskulære, metabolske og nevroendokrine sykdommer i voksen alder ("Developmental Origins of Health and Disease") (31,32). I følge Seckl (31) kan føtal ekspo- 
nering for høye konsentrasjoner av glucocorticoider (for eksempel i forbindelse med maternelt stress?) representere en mekanisme som reduserer føtal vekst. I placenta reduseres overgangen av cortisol fra mor til fosteret ved hjelp av enzymet 11-beta-hydroxysteroid dehydrogenase 2 (11 $\beta$-HSD2). Hos rotter reduseres fødselsvekten ved eksponering for det syntetiske steroidet dexametasone (krysser placenta) eller til carbenoxolone (hemmer 11 $\beta$-HSD2). Hos mennesker forårsaker mutasjon i 11ß-HSD2 lav fødselsvekt. Avkom hvor denne mutasjonen foreligger har høyere nivåer av plasma kortisol som voksne, noe som indikerer en permanent endring av HPA-aksen og ekspresjonen av spesifikke transkripsjonsfaktorer (31). De Weerth og Buitelaar (33) konkluderer i en oversiktsartikkel at maternelt stress i svangerskapet har langtidsvirkning på adferd og fysiologisk utvikling til barnet og tilskriver dette en forhøyet eller unormal aktivitet $i$ den maternelle HPA-aksen i svangerskapet. Det er for øvrig beskrevet sammenheng mellom angst og stress $i$ svangerskapet og for tidlig fødsel (34), dødfødsel (35) og lav fødselsvekt (36).

\section{FORSKNINGSPROSJEKT}

Vi har startet et forskningsprosjekt hvor vi ønsker å identifisere og dokumentere psykiske og hormonelle reaksjoner knyttet til funn av fosteravvik ved ultralydundersøkelse i svangerskapet i relasjon til tidspunkt for diagnose, sosiodemografiske og parentale bakgrunnsvariabler samt variabler relatert til svangerskapet. Studien er tilrådd av Regional etisk komité og finansiert av Norske Kvinners Sanitetsforenings Kvinnefond og Nasjonalt kompetansesenter for kvinnehelse. Kvinnene og eventuelt deres partner er inkludert i studien kort tid etter at de har vært til ultralydundersøkelse og et strukturelt avvik hos fosteret er blitt avdekket. Kontrollgruppen består av gravide med partner hvor det ikke er påvist avvik. Deltagerne blir fulgt med psykometriske tester (f.eks. General Health Questionnaire 28) gjennom flere målepunkt i svangerskapet og en gang etter fødsel. Vi måler blant annet kortisol i spytt og serum og katekolaminer i urin. Tilsvarende longitudinelle studier gjennom svangerskapet er ikke tidligere utført etter at det er avdekket avvik ved fosteret ved ultralydundersøkelser - verken på kvinnen eller partneren. En slik studie bør utføres på en populasjon som får standardisert veiledning og oppfølging etter funn av misdannelser. Ved vår avdeling er dette standardisert som følger: Spesialist i fostermedisin vil følge opp alle. Andre spesialister blir involvert avhengig av problemstilling (type fosteravvik). Vårt prosjekt er i samsvar med en rapport fra Nasjonalt kunnskapssenter for helsetjenesten. De har sett på effekten av tiltak rettet mot gravide med økt risiko for depresjon etter fødselen og slår fast at man bør ha en vid innfallsvinkel til kvinners psykiske helse og "økt oppmerksomhet omkring kvinners psykiske helse allerede tidlig under svangerskapet" (4).

\section{REFERANSER}

1. Lie RT. Studier av årsaker til medfødte misdannelser basert på Medisisk fødselsregister. Norsk Epidemiologi 2007; 17: 141-6.

2. Stoll C, Alembik Y, Dott B, Roth MP. Impact of prenatal diagnosis on livebirth prevalence of children with congenital anomalies. Ann Genet 2002; 45: 115-21.

3. Cunningham FG, Gant NF, Leveno KJ, Gilstrap III LC, Hanth JC, Wenstrom KD. Williams obstetrics. $21^{\text {st }}$ ed. New York: McGraw-Hill, 2005, Chapter 53: 1405-27.

4. Larun L. Svangerskap og psykisk helse. Oslo: Nasjonalt kunnskapssenter for helsetjenesten, 2005.

5. Eberhard-Gran M. Depression in women: with focus on the postpartum period. Oslo: Faculty of Medicine, University of Oslo, 2003.

6. Eberhard-Gran M, Tambs K, Opjordsmoen S, Skrondal A, Eskild A. Depression during pregnancy and after delivery: a repeated measurement study. J Psychosom Obstet Gynaecol 2004; 25: 15-21.

7. Skari H, Skreden M, Malt UF, Dalholt M, Ostensen AB, Egeland T, et al. Comparative levels of psychological distress, stress symptoms, depression and anxiety after childbirth - a prospective population-based study of mothers and fathers. BJOG 2002; 109: 1154-63.

8. Eberhard-Gran M, Eskild A, Tambs K, Samuelsen SO, Opjordsmoen S. Depression in postpartum and nonpostpartum women: prevalence and risk factors. Acta Psychiatr Scand 2002; 106: 426-33.

9. Evans J, Heron J, Francomb H, Oke S, Golding J. Cohort study of depressed mood during pregnancy and after childbirth. BMJ 2001; 323: 257-60.

10. Huizink AC, Mulder EJ, Robles de Medina PG, Visser GH, Buitelaar JK. Is pregnancy anxiety a distinctive syndrome? Early Hum Dev 2004; 79: 81-91.

11. Brisch KH, Munz D, Bemmerer-Mayer K, Terinde R, Kreienberg R, Kachele H. Coping styles of pregnant women after prenatal ultrasound screening for fetal malformation. J Psychosom Res 2003; 55: 91-7. 
12. Bricker L, Garcia J, Henderson J, Mugford M, Neilson J, Roberts T, et al. Ultrasound screening in pregnancy: a systematic review of the clinical effectiveness, cost-effectiveness and women's views. Health Technol Assess 2000; 4: i-193.

13. Sklansky M, Tang A, Levy D, Grossfeld P, Kashani I, Shaughnessy R, et al. Maternal psychological impact of fetal echocardiography. J Am Soc Echocardiogr 2002; 15: 159-66.

14. Leithner K, Maar A, Fischer-Kern M, Hilger E, Loffler-Stastka H, Ponocny-Seliger E. Affective state of women following a prenatal diagnosis: predictors of a negative psychological outcome. Ultrasound Obstet Gynecol 2004; 23: 240-6.

15. Leithner K, Maar A, Maritsch F. Experiences with a psychological help service for women following a prenatal diagnosis: results of a follow-up study. J Psychosom Obstet Gynaecol 2002; 23: 183-92.

16. Brisch KH, Munz D, Kachele H, Terinde R, Kreienberg R. Effects of previous pregnancy loss on level of maternal anxiety after prenatal ultrasound screening for fetal malformation. Journal of Loss and Trauma 2005; 10: 131-53.

17. Langer M, Ringler M. Prospective counselling after prenatal diagnosis of fetal malformations: interventions and parental reactions. Acta Obstet Gynecol Scand 1989; 68: 323-9.

18. Kemp J, Davenport M, Pernet A. Antenatally diagnosed surgical anomalies: the psychological effect of parental antenatal counseling. J Pediatr Surg 1998; 33: 1376-9.

19. Aite L, Trucchi A, Nahom A, Spina V, Bilancioni E, Bagolan P. Multidisciplinary management of fetal surgical anomalies: the impact on maternal anxiety. Eur J Pediatr Surg 2002; 12: 90-4.

20. Aite L, Trucchi A, Nahom A, Zaccara A, La Sala E, Bagolan P. Antenatal diagnosis of surgically correctable anomalies: effects of repeated consultations on parental anxiety. J Perinatol 2003; 23: 652-4.

21. Aite L, Trucchi A, Nahom A, Casaccia G, Zaccara A, Giorlandino C, et al. Antenatal diagnosis of diaphragmatic hernia: parents' emotional and cognitive reactions. J Pediatr Surg 2004; 39: 174-8.

22. Sandelowski M, Jones LC. Couples' evaluations of foreknowledge of fetal impairment. Clin Nurs Res 1996; 5: 81-96.

23. Hunfeld JA, Tempels A, Passchier J, Hazebroek FW, Tibboel D. Brief report: parental burden and grief one year after the birth of a child with a congenital anomaly. J Pediatr Psychol 1999; 24: 515-20.

24. Skari H, Malt UF, Bjornland K, Egeland T, Haugen G, Skreden M, et al. Prenatal diagnosis of congenital malformations and parental psychological distress - a prospective longitudinal cohort study. Prenat Diagn 2006; 26: $1001-9$.

25. Detraux JJ, Gillot-de Vries F, Vanden Eynde S, Courtois A, Desmet A. Psychological impact of the announcement of a fetal abnormality on pregnant women and on professionals. Ann N Y Acad Sci 1998; 847: 210-9.

26. Strauss RP. Beyond easy answers: prenatal diagnosis and counseling during pregnancy. Cleft Palate Craniofac J 2002; 39: 164-8.

27. Egliston KA, McMahon C, Austin MP. Stress in pregnancy and infant HPA axis function: conceptual and methodological issues relating to the use of salivary cortisol as an outcome measure. Psychoneuroendocrinology 2007; 32: 1-13.

28. Severi FM, Prattichizzo D, Casarosa E, Barbagli F, Ferretti C, Altomare A, et al. Virtual fetal touch through a haptic interface decreases maternal anxiety and salivary cortisol. J Soc Gynecol Investig 2005; 12: 37-40.

29. Obel C, Hedegaard M, Henriksen TB, Secher NJ, Olsen J, Levine S. Stress and salivary cortisol during pregnancy. Psychoneuroendocrinology 2005; 30: 647-56.

30. Kammerer M, Adams D, Castelberg BB, Glover V. Pregnant women become insensitive to cold stress. $B M C$ Pregnancy Childbirth 2002; 2: 8.

31. Seckl JR. Prenatal glucocorticoids and long-term programming. Eur J Endocrinol 2004; 151 (Suppl 3): U49U62.

32. Gluckman PD, Hanson MA, Cooper C, Thornburg KL. Effect of in utero and early-life conditions on adult health and disease. N Engl J Med 2008; 359: 61-73.

33. de Weerth C, Buitelaar JK. Physiological stress reactivity in human pregnancy - a review. Neurosci Biobehav Rev 2005; 29: 295-312.

34. Goland RS, Jozak S, Conwell I. Placental corticotropin-releasing hormone and the hypercortisolism of pregnancy. Am J Obstet Gynecol 1994; 171: 1287-91.

35. Wisborg K, Barklin A, Hedegaard M, Henriksen TB. Psychological stress during pregnancy and stillbirth: prospective study. BJOG 2008; 115: 882-5.

36. Wadhwa PD, Garite TJ, Porto M, Glynn L, Chicz-Demet A, Dunkel-Schetter C, et al. Placental corticotropinreleasing hormone $(\mathrm{CRH})$, spontaneous preterm birth, and fetal growth restriction: a prospective investigation. Am J Obstet Gynecol 2004; 191: 1063-9. 